\title{
PROGRAM SANGKUTAN INDUSTRI PENSYARAH DIKALANGAN PEGAWAI PENDIDIKAN PENGAJIAN TINGGI (PPPT) JABATAN PELANCONGAN DAN HOSPITALITI
}

\author{
Wido Mes Wati Binti Sukadi, Noor Afizah Binti Atan, Rahimawati Binti Abdul Rahim \\ wd_wido@yahoo.com,fizah75@yahoo.com.my,rar_ros@yahoo.com \\ Jabatan Pelancongan dan Hospitaliti, Politeknik Johor Bahru,
}

\begin{abstract}
Abstrak
Tenaga pengajar institusi pendidikan perlu menguasai kemahiran teori dan amali untuk melahirkan graduan-graduan yang menepati kehendak industri. Tenaga pengajar politeknik digalakkan mengikuti latihan di industri agar segala perubahan teknologi dan perkembangan pesat industri dapat diikuti. Kajian ini bertujuan untuk melihat tahap pengetahuan PPPT Jabatan Pelancongan dan Hospitaliti terhadap program sangkutan industri pensyarah (SIP) dan hubungannya dengan tempoh mereka berkhidmat. Selain itu, kajian ini juga ingin melihat faktorfaktor PPPT tidak memohon program SIP. Responden adalah terdiri daripada 43 orang PPPT Jabatan Pelancongan dan Hospitaliti, Politeknik Johor Bahru. Data-data dianalisis menggunakan Statistical Packages for Social Sciences Version 11.5 (SPSS). Dapatan kajian ini mendapati tahap pengetahuan PPPT terhadap program SIP berada di tahap sederhana dengan skor min 2.98. Ujian Oneway ANOVA menunjukkan tidak wujud perbezaan yang signifikan diantara tempoh berkhidmat dengan tahap pengetahuan terhadap program SIP. Dapatan kajian juga mendapati faktor utama yang menyebabkan PPPT tidak memohon SIP adalah kerana bebanan tugas di jabatan yang banyak. 5 orang PPPT yang telah menjalani program SIP berpendapat program ini dapat meningkatkan kemahiran dan pengetahuan. Kesimpulan dalam kajian ini, walaupun tahap pengetahuan PPPT terhadap program SIP adalah sederhana, namun pandangan mereka terhadap program SIP adalah program ini amat perlu dan penting dalam meningkatkan lagi kecekapan dan kebolehan tenaga pengajar yang mana secara tidak langsung akan mempengaruhi kualiti graduan seterusnya meningkatkan kebolehpasaran graduan politeknik.
\end{abstract}

\section{INTRODUCTION}

Perkembangan pesat yang berlaku dalam bidang sains dan teknologi di peringkat global adalah diantara faktor berlakunya perubahan persekitaran di tempat kerja. Untuk meneruskan persaingan dan kehidupan dalam dunia globalisasi ini, pembelajaran sepanjang hayat adalah penting bukan sahaja kepada anak muda tetapi juga kepada mereka yang sudah lama bekerja. Menurut Snewin dan Hashim 1999:,Ramlee et al 2003, pengalaman di industri yang berkaitan adalah penting bagi tenaga pengajar yang mengajar subjek teknikal dan vokasional di institusi yang menawarkan program berkaitan teknik dan vokasional seperti politeknik .Di Malaysia, politeknik merupakan institusi pengajian tinggi yang bertujuan untuk menghasilkan tenaga kerja separa profesional yang berkualiti bagi menampung keperluan sektor awam dan swasta negara. Oleh itu adalah penting bagi tenaga pengajar politeknik sentiasa mengikuti perkembangan semasa untuk memastikan kemahiran mereka relevan dengan pasaran kerja dan industri.

Laporan 'Polytechnic Development Project Employer Study' oleh IDP Education Australia dan National Center for Vocational Education Research (NCVER) tahun 1999, telah menyatakan bahawa kekurangan pengalaman industri di kalangan pensyarah-pensyarah politeknik yang mana telah memberi kesan terhadap kualiti graduan politeknik. Laporan tersebut telah mencadangkan supaya pensyarah politeknik diberi peluang untuk mengikuti program sangkutan (attachment) di industri yang berkaitan dengan keperluan kursus di politeknik. Oleh itu, program latihan dalam perkhidmatan yang merangkumi penempatan pensyarah di industri yang bersesuaian telah diperkenalkan.

Mesyuarat Pengurusan Kementerian Pendidikan Malaysia (Bil. 22 Tahun 1999) 
pada 14 Julai 1999 telah meluluskan pelaksanaan program sangkutan ke industri setiap tahun bagi pensyarah-pensyarah politeknik. Selepas tahun 1999, pelbagai kaedah dan penambahbaikan telah diperkenalkan dalam memperbaiki pelaksanaan program tersebut. Di antaranya, mulai tahun 2006, program ini ditawarkan dalam dua sesi pengambilan setahun iaitu pada bulan April dan Julai. Ini adalah bertujuan untuk memberi fleksibiliti kepada pensyarah untuk membuat perancangan serta memilih masa yang paling sesuai untuk menjalani latihan. Ini juga untuk mengatasi isu pensyarah yang tidak mendapat pelepasan Ketua Jabatan atas alasan kekurangan bilangan pensyarah. Bermula tahun ini tempoh latihan adalah lebih fleksibel iaitu tempoh minimum 1 bulan dan maksimum 3 bulan.

(Bahagian Latihan dan Pembangunan Kerjaya, Jabatan Pengajian Politeknik

\section{Latar belakang masalah}

Latihan dan pendidikan tenaga pengajar dalam bidang kemahiran teknikal dan vokasional adalah penting kerana perubahan teknologi di industri terlalu pantas. Oleh itu, tenaga pengajar teknikal dan vokasional perlu sentiasa peka dengan perubahan pelajar dan keperluan tenaga kerja. Menurut Bottoms dan McNally (2008) tenaga pengajar masa kini mempunyai dua misi iaitu menyediakan pelajar untuk persediaan mengharungi alam pekerjaan dan juga untuk mereka melanjutkan pelajaran. Oleh itu, Bottoms dan McNally menyarankan institusi pendidikan memerlukan tenaga pengajar yang berkelayakan untuk mencapai misi tersebut. Bagi mencapai tujuan ini, para pensyarah perlulah kompeten tidak hanya dalam aspek pedagogi penyampaian teori dalam bidang yang diajar tetapi juga perlu juga pengalaman industri untuk meningkatkan kemahiran praktikal yang merujuk kepada amalan kerja sebenar yang diamalkan di industri.

Program Sangkutan Industri Pensyarah (SIP) untuk pensyarah politeknik telah disyorkan sebagai sebagai satu program pembangunan pensyarah politeknik untuk meningkatkan kemahiran dan pengetahuan melalui pendedahan industri. Program ini bukan sahaja memberi penekanan kepada ilmu teori tetapi juga seiring dengan perkembangan teknologi di sektor industri disamping memberi pendedahan kepada budaya kerja dalam pelbagai sektor di industri. Selain itu, Bahagian Pembangunan dan Latihan Staf mengharapkan program ini akan membantu dalam peningkatan pengajaran dan sistem pembelajaran di politeknik melalui peningkatan kurikulum politeknik. Pengetahuan dan kemahiran yang diperolehi akan dimasukkan ke dalam pengajaran dan pembelajaran dalam rangka meningkatkan kualiti graduan politeknik. Program ini juga diharapkan untuk membolehkan pensyarah diiktiraf sebagai professional di bidang masing-masing. Ini kerana pada masa ini, pensyarah di politeknik tidak diiktiraf sebagai professional oleh badan-badan professional. Pensyarah yang telah menjalani latihan juga diharapkan dapat berkongsi pengalaman dan pengetahuan yang diperolehi bersama staf lain melalui seminar atau in house training dan juga menyumbang dalam bentuk penulisan akademik. Program ini juga diharapkan dapat mengukuhkan kerjasama di antara politeknik dan pihak industri.

(Kementerian Pendidikan Malaysia)

Menurut Hanizah (2008), peratusan pensyarah yeng telah mengikuti program SIP sehingga tahun 2008 hanya 4\% daripada jumlah keseluruhan staf akademik. Hanya $1 \%$ sahaja penglibatan pensyarah dari bidang Hospitaliti berbanding pensyarah jabatan-jabatan lain di politeknik seluruh Malaysia. Penglibatan tertinggi adalah dari Jabatan Kejuruteraan Elektrik (27\%), Kejuruteraan Awam (25\%), Perdagangan (19\%), Kejuruteraan Mekanikal (17\%), Pengajian Am (6\%), Teknologi Maklumat (3\%) dan lain-lain(2\%).

Berdasarkan kenyataan ini, kajian ini bertujuan untuk melihat tahap pengetahuan PPPT Jabatan Pelancongan dan Hospitaliti, Politeknik Johor Bahru terhadap program sangkutan industri pensyarah dan faktorfaktor PPPT tidak memohon program tersebut.

\section{Penyataan masalah}

Latihan dan pendidikan tenaga pengajar teknikal dalam bidang kemahiran adalah penting kerana perubahan teknologi di industri terlalu pantas. Seperti yang dinyatakan didalam Pelan Strategik Pengajian Tinggi Negara, isu pengangguran 
di kalangan siswazah sering dibangkitkan dan dikaitkan dengan ketidaksepadanan di antara kebolehan graduan IPT dengan kemahiran yang diperlukan oleh pihak industri. Persepsi majikan masih wujud bahawa kualiti graduan universiti luar negara adalah lebih baik berbanding dengan graduan tempatan. Program ini adalah satu saluran yang penting unutk memaklumkan kepada industri tentang aktiviti pelajar, anugerah serta pengiktirafan yang diterima oleh graduan politeknik. Selain daripada itu, input daripada pihak industri tentang amalan terkini, teknologi semasa, kepakaran dan sebagainya adalah sangat penting untuk pembangunan bidang akademik negara.

Oleh yang demikian kajian ini dijalankan untuk mengetahui tahap pengetahuan pensyarah Jabatan Pelancongan dan Hospitaliti, Politeknik Johor Bahru terhadap program SIP dan mengenalpasti adakah tempoh perkhidmatan mempengaruhi pengetahuan mereka terhadap program SIP. Kajian ini juga bertujuan untuk mengenalpasti faktor-faktor pensyarah tidak memohon program SIP.

\section{Objektif kajian}

Kajian ini bertujuan untuk:

1. Mengetahui tahap pengetahuan Pegawai Pendidikan Pengajian Tinggi (PPPT) terhadap program SIP.

2. Mengenalpasti perbezaan tempoh berkhidmat dengan tahap pengetahuan Pegawai Pendidikan Pengajian Tinggi (PPPT) terhadap program SIP.

3. Mengenalpasti faktor-faktor Pegawai Pendidikan Pengajian Tinggi (PPPT) tidak memohon progam SIP.

\section{Persoalan kajian}

1. Adakah wujud tahap kesediaan pengetahuan Pegawai Pendidikan Pengajian Tinggi (PPPT) terhadap program SIP.

2. Adakah terdapat perbezaan faktor tempoh berkhidmat dengan dengan tahap pengetahuan Pegawai Pendidikan Pengajian Tinggi (PPPT) terhadap program SIP.
3. Apakah faktor-faktor yang menyebabkan Pegawai Pendidikan Pengajian Tinggi (PPPT) tidak memohon program SIP

\section{LITERATURE REVIEW}

\section{Program Sangkutan Industri Pensyarah (SIP)}

Sejak program sangkutan industri pensyarah (SIP) dimulakan, seramai 449 pensyarah telah mengikuti latihan dengan 381 syarikat. Pada tahun 2009 sahaja, 61 orang pensyarah telah menjalani program sangkutan dalam 59 syarikat. (Imran, 2008)

Proses dalam program sangkutan industri pensyarah terbahagi kepada tiga peringkat iaitu sebelum, semasa dan selepas. Sebelum latihan, calon-calon yang berminat mengikuti program latihan sangkutan ke industri perlu mendapatkan tempat latihan yang sesuai dan berkaitan dengan bidang masing-masing. Keutamaan akan diberi kepada syarikat yang tersenarai dalam cadangan jabatan dan bertaraf multinasional. Ini merupakan tugas awal yang memerlukan para pensyarah berkomunikasi dengan industri. Peringkat seterusnya adalah semasa menjalani program sangkutan di industri. Pensyarah dijangka akan terdedah kepada pelbagai lapangan kerja seperti penyelenggaraan teknikal, operasi, pengurusan dan sebagainya. Jadual tugas adalah mengikut yang telah ditetapkan oleh organisasi. Sepanjang program, pensyarah akan diselia oleh seorang penyelia di organisasi. Pegawai dari Bahagian Latihan \& Pembangunan Kerjaya, JPT yang bertanggungjawab juga akan datang melawat pensyarah untuk memantau dan menilai kemajuan mereka. Selepas tamat latihan, pensyarah perlu menyiapkan laporan berkaitan pencapaian mereka dalam program dan berkongsi pengetahuan serta pengalaman bersama-sama rakan setugas melalui seminar atau kurus jangka pendek.

Program SIP merupakan salah satu daripada bentuk kerjasama di antara politeknik dan pihak industri. Peranan penyelia, penyelaras dan pelatih program SIP boleh ditunjukkan seperti berikut (Ruhizan et.al) 


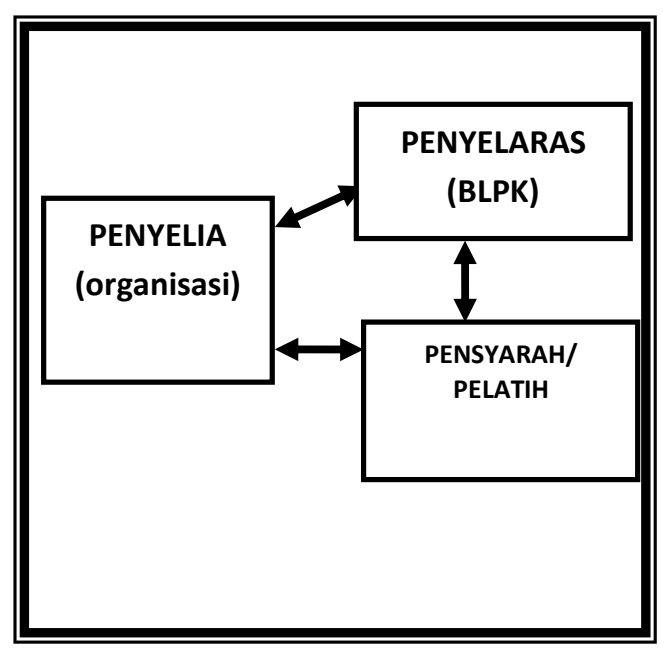

Sumber : Ruhizan et.al(online)

Rajah 1 : Peranan penyelia, penyelaras dan pelatih dalam Program SIP

Menurut M. Fadzil et.al (2011), objektif program sangkutan industri pensyarah (SIP) tercapai iaitu mendedahkan pensyarah kepada alam pekerjaan di industri seterusnya dapat membangunkan dan meningkatkan kemahiran professional dan peribadi mereka. Pensyarah juga dapat berkongsi maklumat dan idea kepada industri seterusnya dapat mewujudkan kerjasama di antara politeknik dan pihak industri.

Hasil dari kajian lepas menunjukkan bahawa program sangkutan industri pensyarah (SIP) memberi kesan yang positif kepada pensyarah dari segi membangunkan ilmu pengetahuan, kemahiran dan sikap. Ia juga mendapati bahawa program latihan ini telah berjaya mempersiapkan pensyarah dengan perkembangan terkini dalam industri, memperkukuhkan pemahaman mereka tentang hubungan antara teori dan amalan sebenar di tempat kerja, dan juga meningkatkan gaya pengajaran mereka. (Baharudin 2004;WanZalia,2005) .

Kesimpulannya, pembelajaran berasaskan kerja adalah penting untuk memberi peluang kepada pensyarah mendapatkan latihan dan peroses pembelajaran di alam pekerjaan sebenar. (Mitchell, Henry\& Young, 2001).

\section{Latihan Di Tempat Kerja}

Menurut Michael dan Diane (2008), latihan ialah mengenai pembangunan pengetahuan dan kemahiran untuk digunakan segera atau pada masa hadapan. Latihan terbahagi antara pembangunan individu yang telah bekerja atau yang baru memasuki alam pekerjaan tersebut. Di mana latihan untuk individu yang sudah bekerja adalah untuk meningkatkan prestasi kerja dan bagi individu yang baru menceburi alam pekerjaan adalah untuk memberi persediaan kepada mereka untuk menunjukkan prestasi kerja dalam lingkungan rangka kerja organisasi sehingga cara atau tingkah mencapai kepuasan.

Pelbagai kaedah dalam bidang latihan wujud, satu daripadanya ialah "On The Job Training” (OJT). Ia sering digunakan oleh syarikat-syarikat yang telah berjaya dalam membentuk pengalaman di tempat kerja, pembelajaran berstruktur dan latihan industri. Gaya latihan ini tidak memerlukan ruang dan peralatan khusus dan berkait rapat dengan kerja yang sedang diamalkan. Oleh kerana itu ia merupakan teknik latihan yang menyelami masalah tempat kerja sebenar (Henry, 2000).

Pembelajaran yang berterusan tidak hanya membantu meningkatkan kemahiran, ia juga dapat melahirkan lebih ramai pakar dalam sesuatu bidang. Pembelajaran tidak hanya berlaku di sekolah atau di institusi pengajian sahaja tetapi juga di tempat kerja kerana keadaan persekitaran yang sering berubah disebabkan perubahan arus teknologi. Pembelajaran bagi orang dewasa atau pekerja yang telah lama adalah perlu disebabkan perubahan teknologi yang digunakan ditempat kerja. Latihan dan pembangunan, pembangunan sumber manusia, pendidikan semula dan latihan semula perlu dipertingkatkan dari semasa untuk memastikan semua pekerja diberi latihan dan pendidikan untuk meningkatkan kemahiran.

Menurut Mimi et.al,(2009) latihan di tempat kerja mempunyai beberapa manfaat iaitu dapat meningkatkan produktiviti, meningkatkan kepuasan kerja, mengikuti perkembangan semasa dan memotivasikan pekerja.

Tapomoy (2005) menyatakan latihan ialah proses yang sistematik dan dirancang untuk meningkatkan pengetahuan, kemahiran dan sikap pekerja. Latihan yang disediakan menyediakan pembelajaran berdasarkan pengalaman kepada pekerja untuk 
membangunkan keupayaan mereka dan meningkatkan prestasi kerja. Selain itu juga, latihan juga membantu organisasi dalam perancangan sumber manusia dengan melahirkan individu yang kompeten dan bermotivasi. Latihan difokuskan kepada menguasai ilmu, kemahiran dan sikap yang mana ianya salah satu strategi organisasi. Latihan juga merupakan modal pelaburan dalam teknologi dan kemahiran kerja untuk meningkatkan produktiviti.

Olehitu,

tenagapengajarperlusentiasameningkatkanke mahirandalambidangteknikaldanvokasionals upayakemahiransentiasasesuaidengankehend aksemasaindustridalammemberilatihandanpe ndidikankepadapelajar.

\section{III.METHODOLOGY}

Kajian ini berbentuk kajian kuantitatif. Ini kerana mengikut Cohan dan Monion (Mohamad Najib, 1999), kajian kes adalah satu usaha untuk mengkaji satu-satu unit pada satu-satu masa untuk melihat secara intensif peristiwa yang berlaku.

Data-data dalam kajian ini diperolehi daripada pensyarah Jabatan Pelancongan dan Hospitaliti, Politeknik Johor Bahru. Populasi kajian difokuskan kepada keseluruhan 43 orang PPPT yang berkhidmat di Jabatan Pelancongan dan Hospitaliti. Dalam kajian ini responden mewakili $100 \%$ persampelan. Rasional pemilihan kumpulan ini sebagai responden ialah dapatan yang diperolehi dapat mempotretkan ciri-ciri keseluruhan populasi yang dikaji.

Kajian ini menggunakan borang kajiselidik untuk mengumpulkan data. Menurut Oppenheim di dalam buku Penyelidikan Pendidikan (Mohamad Najib, 1999) kaedah memperolehi data secara soal selidik mampu mengukur konsep yang berkaitan dengan sikap, persepsi serta pandangan.

Bentuk soalan di bahagian A adalah mengikut aneka pilihan. Manakala bahagian $\mathrm{B}$ dan $\mathrm{C}$, semua soalan disusun dengan menggunakan skala likert untuk mengukur tahap pengetahuan PPPT terhadap Program SIP dan mengetahui faktor-faktor PPPT tidak mengikuti program SIP. Skala ini sesuai digunakan kerana menurut Wierman (1995), ia merupakan satu inventori sikap yang melibatkan perasaan individu terhadap sesuatu idea, prosedur dan institusi sosial.

Bagi PPPT yang pernahmengikuti program SIP, merekaperlumengisiBahagian D. Bahagianinimemerlukanrespondanmenjawab soalan di tempatkosong yang disediakan.

Kaedah peratusan telah digunakan untuk bahagian A : Profile PPPT dan bahagian C : Mengapa tidak mengikuti program SIP. Manakala semua data di bahagian B telah dianalisi dengan menggunakan perisian SPSS.

Bagi soalan kajian 1, kaedah deskriptif statistik telah digunakan dengan berpandukan min skor. Ini kerana analisis min boleh digunakan untuk mengukur skor purata yang membawa kepada gambaran data secara keseluruhan (Uma Sekaran, 1992). Data berkenaan telah ditafsirkan dengan menggunakan Jadual 1 dibawah (Alias Baba, 1999).

Jadual 1 : Tafsiran min dan tahap pengetahuan terhadap SIP

\begin{tabular}{|l|l|l|}
\hline Min & Tafsiran & $\begin{array}{l}\text { Tahap } \\
\text { Pengetahuan }\end{array}$ \\
\hline $\begin{array}{l}1.00 \\
\text { hingga } \\
2.49\end{array}$ & $\begin{array}{l}\text { Tidak setuju dan } \\
\text { sangat tidak } \\
\text { setuju }\end{array}$ & Rendah \\
\hline $\begin{array}{l}2.50 \\
\text { hingga } \\
3.49\end{array}$ & Kurang setuju & Sederhana \\
\hline $\begin{array}{l}3.50 \\
\text { hingga } \\
5.00\end{array}$ & Setuju dan sangat & Tinggi \\
\hline
\end{tabular}

Bagi soalan kajian 2, kaedah analisis data yang dijalankan ialah dengan menggunakan Ujian Oneway ANOVA. Menurut Mohd Salleh dan Zaidatun (2001), Ujian Oneway ANOVA boleh dijalankan untuk menguji perbezaan min bagi pembolehubah bersandar untuk dua kumpulan atau lebih secara serentak. Dalam ujian ini, jika kebarangkalian berlakunya fenomena ini adalah kurang 0.025 atau $2.5 \%$, maka hopotesis nol adalah ditolak. Ini bermakna wujudnya perbezaan min yang signifikan bagi pembolehubah yang dikaji dikalangan ketiga-tiga kumpulan populasi.

Bagi soalan kajian 3, kaedah analisis data yang digunakan adalah peratusan dan graf. 
Pengkaji telah menggabungkan pilihan 1 (sangat tidak setuju dan 2 (tidak setuju) sebagai pilihan tidak setuju. Manakala pilihan 3 (setuju) dan 4 (sangat setuju) sebagai pilihan setuju. Penggabungan skala keputusan ini ditunjukkan di dalam Jadual 2 terlampir.

\section{<Lampiran Tabel-2>}

Jadual 2: Penggabungan skala keputusan data soal selidik

\section{Batasan kajian dan andaian}

Kajian ini hanya melihat tahap pengetahuan Pegawai Pendidikan Pengajian Tinggi (PPPT) di Jabatan Pelancongan dan Hospitaliti Politeknik, Johor Bahru terhadap program sangkutan industri pensyarah dan faktor-faktor yang mempengaruhi mereka tidak memohon program ini.

Satu andaian telah dibuat iaitu semua responden menjawab soalan di dalam borang soalselidik dengan jujur dan ikhlas.

\section{RESULT AND DISCUSSION}

\section{Bahagian A : Profil PPPT}

Jadual 3 di bawah menunjukkan jumlah responden yang terlibat dalam kajian mengikut jantina. Jumlah responden perempuan ialah 35 orang $(81.4 \%)$ dan jumlah responden lelaki ialah 8 orang ( $18.6 \%)$.

\section{<Lampiran Tabel-3>}

\section{Jadual 3 : Jantina Responden}

Jadual 4 di bawah menunjukkan taburan gred jawatan responden. Responden yang di dalam gred DH 29/32/34 seramai 2 orang (4.7\%), DH 41 seramai 38 orang ( $88.4 \%$ ) dan DH 44 seramai 3 orang (7\%).

\section{<Lampiran Tabel-3>}

Jadual 4 : Gred Jawatan Responden

Jadual 5 di bawah menunjukkan tempoh berkhidmat untuk 43 orang respondan.

$<$ Lampiran Tabel-5>

Jadual 5 : Tempoh Berkhidmat
Dapatan juga menunjukkan $11.6 \%$ (5 orang) responden pernah mengikuti program SIP, manakala $88.4 \%$ (38 orang) belum pernah mengikut program tersebut.

\section{Bahagian B : Tahap Pengetahuan PPPT Terhadap Program Sangkutan Industri Pensyarah (SIP)}

\section{Persoalan kajian 1}

Analisa kajian dibahagian ini adalah merujuk kepada persoalan kajian 1 iaitu "Adakah wujud tahap pengetahuan Pegawai Pendidikan Pengajian Tinggi (PPPT) terhadap program SIP”.

Tahap pengetahuan PPPT diukur dengan menggunakan min skor bagi setiap soalan. Jadual 6 di bawah menunjukkan dapatan min skor bagi tahap pengetahuan yang dikaji.

\section{<Lampiran Tabel-6>}

Jadual 6: Min Keseluruhan bagi tahap pengetahuan PPPT terhadap program SIP

Dapatan daripada analisis telah menunjukkan bahawa PPPT sedar tentang kewujudan program Sangkutan Industri Pensyarah. Ini dapat dilihat daripada nilaian min yang diperolehi adalah 3.63. Walaubagaimanapun kefahaman dan kesedaran PPPT tentang kepentingan, kaedah permohonan dan syarat-syarat permohonan program SIP masih lagi sederhana. Ini dibuktikan dengan nilaian min yang diperolehi bagi ketiga-tiga item tersebut adalah diantara 2.50 hingga 3.49 . Selain itu kefahaman PPPT mengenai kriteria pemilihan tempat latihan SIP, tatacara permohonan, tempoh program dan kesedaran mengenai tuntutan serta kadar elaun menghadiri SIP dan elaun perjalanan masih lagi sederhana. Pengetahuan PPPT terhadap tanggungjawab yang perlu dilaksanakan selepas tamat program SIP juga masih lagi sederhana. Ini dapat disokong dengan bacaan nilaian min diantara 2.50 hingga 3.49 .

Oleh yang demikian, secara keseluruhan tahap pengetahuan PPPT Jabatan Pelancongan dan Hospitaliti di Politeknik Johor Bahru terhadap program Sangkutan Industri Pensyarah masih lagi sederhana. Ini 
kerana purata nilaian min yang diperolehi adalah 2.98 .

\section{Persoalan kajian 2}

Analisis kajian ini adalah untuk mengenalpasti samada terdapat perbezaan tempoh berkhidmat dengan tahap pengetahuan Pegawai Pendidikan Pengajian Tinggi (PPPT) terhadap program SIP . Dapatan Ujian Oneway ANOVA yang dijalankan adalah seperti Jadual 7 dibawah :

\section{<Lampiran Tabel 7>}

Jadual 7 : Dapatan Ujian Oneway ANOVA

Dapatan Ujian Oneway ANOVA yang dijalankan menunjukkan kesemua soalan memperolehi nilai signifikan yang lebih besar daripada 0.025 atau $2.5 \%$. Ini bermakna tidak wujud perbezaan min secara signifikan bagi pembolehubah yang dikaji antara keempat-empat populasi. Kesimpulannya tidak terdapat perbezaan yang signifikan diantara tempoh berkhidmat dengan tahap pengetahuan Pegawai Pendidikan Pengajian Tinggi (PPPT) terhadap program SIP .

\section{Bahagian C : Faktor-Faktor PPPT Tidak Memohon Program SIP}

\section{Persoalan kajian 3}

Analisis data bagi persoalan kajian ini adalah seperti Jadual 8 dibawah :

\section{<Lampiran Tabel 7>}

Jadual 8: Faktor-faktor tidak mengikuti Program SIP

Berdasarkan Jadual 8 tersebut, faktor utama yang menyebabkan PPPT di Jabatan Pelancongan dan Hospitaliti tidak memohon Program SIP adalah kerana bebanan tugas di jabatan yang banyak untuk diselesaikan. Ini dibuktikan dengan $72.1 \%$ responden bersetuju dengan faktor yang dinyatakan. Faktor kekangan yang kedua adalah berkaitan dengan urusan keluarga, dimana ia menunjukkan $48 \%$ responden bersetuju bahawa sekiranya mengikuti program SIP, maka urusan keluarga banyak terganggu. Faktor -faktor lain yang mempengaruhi PPPT tidak memohon Program SIP ialah senarai tempat latihan yang terhad (48.8\%), tiada galakan dari pihak pengurusan $(41.8 \%)$, kerumitan prosedur $(41.9 \%)$, sesi pengambilan yang tidak sesuai (34.9\%), tiada kerjasama dari pihak industri $(25.6 \%)$, tidak mahu tugas tambahan selepas menjalani Program SIP (23.3\%), bukan bidang hospitaliti $(23.3 \%)$ dan tiada manfaat untuk P\&P (9.3\%).

Terdapat 5 orang PPPT di Jabatan Pelancongan dan Hospitaliti yang telah mengikuti program SIP. Mereka berpendapat bahawa program ini banyak memberi manfaat kepada pensyarah dalam meningkatkan kemahiran dan pengetahuan. Secara tidak langsung ianya dapat meningkatkan kualiti proses pengajaran dan pembelajaran. Pendapat ini disokong oleh Mohamad Fadzil dan Kamarul Ariffin (2011) yang menyatakan program SIP membolehkan PPPT mengetahui teknologi terkini dalam dunia industri yang sebenar.

\section{CONCLUSION}

Berdasarkan dapatan yang diperolehi daripada kajian ini merumuskan bahawa tahap pengetahuan Pegawai Pendidikan Pengajian Tinggi (PPPT) Jabatan Pelancongan dan Hospitaliti terhadap program SIP adalah pada tahap sederhana. Tempoh berkhidmat PPPT tidak mempengaruhi tahap pengetahuan mereka terhadap program SIP. Faktor utama yang menyebabkan PPPT tidak memohon Program SIP adalah kerana bebanan tugas di jabatan yang banyak untuk diselesaikan. Ini diikuti oleh faktor-faktor lain seperti urusan keluarga, senarai tempat latihan yang terhad, kerumitan prosedur, tiada galakan dari pihak pengurusan, sesi pengambilan yang tidak sesuai, tiada kerjasama dari pihak industri , tidak mahu tugas tambahan selepas menjalani Program SIP, bukan bidang hospitaliti dan tiada manfaat untuk P\&P . Respon daripada PPPT yang telah menjalani program SIP adalah positif di mana semua mereka bersetuju bahawa program ini banyak memberi manfaat kepada pensyarah dalam meningkatkan kemahiran dan pengetahuan. Secara tidak langsung ianya dapat meningkatkan kualiti proses pengajaran dan pembelajaran. 
Bagi memastikan keberkesanan jaringan kolaborasi dengan pihak industri, pihak politeknik perlu memainkan peranan proaktif dan membuat pemantauan secara berterusan terhadap program SIP. Diharapkan agar pihak politeknik atau bahagian Latihan dan Pembangunan Kerjaya, JPT supaya dapat menyenaraikan lebih banyak tempat latihan yang berkaitan dengan Pelancongan dan Hospitaliti. Hebahan atau promosi berkaitan program SIP dan kepentingannya perlu dibuat bukan sahaja kepada warga politeknik malahan juga kepada pihak industri. Kolaborasi dengan industri boleh dibuat melalui Persatuan Perhotelan Malaysia(MAH) dan Persatuan Agensi Pelancongan dan Pengembaraan Malaysia(MATTA).

Program SIP juga boleh diperluaskan ke luar negara bagi mendedahkan pensyarah kepada budaya, bahasa, cara bekerja dan teknologi luar negara. Pengalaman yang bakal diperolehi boleh disampaikan kepada pelajar sebagai galakan kepada mereka mempersiapkan diri dengan cabaran globalisasi.

Sebagai rumusannya, program SIP adalah amat penting bagi pensyarah untuk menimba kemahiran dan pengalaman serta mengikuti perkembangan teknologi terkini. Diharapkan agar lebih ramai lagi PPPT Jabatan Pelancongan dan Hospitaliti mengikuti program SIP di masa akan datang untuk melahirkan pasukan pendidik yang professional dan berdedikasi seterusnya menghasilkan graduan industry pelancongan dan hotel catering selaras dengan aspirasi negara.

\section{References}

Alias Baba, 1999. Statistik Penyelidikan Dalam Pendidikan Sains Sosial. Edisi Pertama. Selangor : Penerbit America $\therefore$ Johan Wiley \& Sons Inc.

Bahagian Latihan \& Pembangunan Kerjaya, Jabatan Pengajian Politeknik. Http://www.jppkk.gov.my

Baharuddin b. Azit. (2004) Kepentinganlatihansangkutan industri terhadappensyarahdalamprosespengaj arandanpembelajaran perspektifpelajar,

ProjekSarjana,
KolejUniversiti Teknologi Tun Hussein Onn.

Bottoms, G., \& McNally, K. (2008). Actions states can take to place a highly qualified career/technical teacher in every classroom. Atlanta, GA: Southern Regional Education Board.

Henry, C.W. (2000). Emergency Response Preparedness: Part 1 - Training and LearningStyle. MCB: University Press.

Imran, I. (2008). Presentation Status Report and Feedback on Issues Raised during Industry Dialogue 2008.

KementerianPendidikan Malaysia (KPM) (1999a) Garispanduan: Program LatihanSangkutanke Industri pensyarah-pensyarahpoliteknik, BahagianLatihan dan Kemajuan Staf,

Michael D. Tovey And Diane R. Lawlor (2008). Training in Australia. Australia. Pearson - Education Australia

Mimi Mohaffyza Mohamad, Che Munira Che Razali, (2009) The Need of Lifelong Learning For Instructors In Vocational Training Institutions, Universiti Tun Hussein Onn Malaysia, Suhaili Abd Jalil, Universiti Sains Islam Malaysia

Mitchell, J., Henry, J. \& Young, S. (2001). Work based Learning in the Contemporary Australian VET Sector: A Reappraised. Reframing the Future Research Project.

Mohamad Fadzil Basir Ahmad, Kamarul Ariffin Abd Rashid (2011), Lecturers' Industrial Attachment Programme to Increase Lecturers' Soft Skill and Technological Competencies for Global Stability and Security, Politeknik Seberang Perai, Penang, Malaysia

Mohamad Najib Abdul Ghafar, 1999. Penyelidikan Pendidikan. Edisi Pertama. Johor : Universiti Teknologi

Mohd Salleh Abu dan Zaidatun Tasir, 2001. Pengenalan Kepada Analisis Data Berkomputer : SPSS 10.0

Pelan Strategik Pengajian tinggi Negara. Http://www.mohe.gov.my/transforma si

Ramlee Mustapha, Ruhizan Mohd. Yasin and Hamdan Mohd. Ali. (2003) 'Integrasiakademik dan vokasional: Rasional dan cabaran', JurnalPendidikan, 28:77-90. 
Ruhizan M. Yasin, Naimah Khalil, Mohammad Sani Ibrahim, Ramlee Mustapha, Noraishah Buang, Competence development through inservice training at the workplace for Malaysian polytechnic lecturers, www.dpu.dk/fileadmin/www.dpu.dk/ .../resources_2259.doc

Snewin, D.G. and Hashim, Mohd. (1999) A report to MARA management: Short form occupational and training needs analysis for electronics industry, Kuala Lumpur: MARA TVE Division.

Tapomoy Deb (2006). Training and Development: Concept and Application. Ane Books India.

Uma Sekaran (1992) Research Method for Business : A Skill Building Approach. $2^{\text {nd }}$ Edition. United States of Universiti Kebangsaan Malaysia

UNEVOC (1997) Training of teachers/trainers in technical and vocational education, Brazil: UNEVOC.

WanZaliabt. WanZahari (2005) KeberkesananLatihanSangkutanke Industri di kalanganpensyarahpoliteknik, ProjekSarjana, KolejUniversiti Teknologi Tun Hussein Onn

Weirma, W, (1995) Research Methods in Education : An Introduction. $6^{\text {th }}$ Edition, London: Allyn and Bacon. Windows. Edisi Perta,a. Kuala Lumpur : Venton Publishing. 


\section{Lampiran}

Tabel 2

Jadual 2: Penggabungan skala keputusan data soal selidik

\begin{tabular}{|l|l|l|}
\hline Tahap likert & Respon PPPT & Keputusan \\
\hline 4 & Sangat setuju & Setuju \\
3 & Setuju & Tidak setuju \\
\hline 2 & Tidak setuju & \\
1 & Sangat tidak setuju & \\
\hline
\end{tabular}

Tabel 3

Jadual 3 : Jantina Responden

\begin{tabular}{|l|l|l|}
\hline Jantina & Bilangan Responden & Responden \% \\
\hline Lelaki & 8 & 18.6 \\
\hline Perempuan & 35 & 81.4 \\
\hline Jumlah & 43 & 100 \\
\hline
\end{tabular}

\section{Tabel 4}

Jadual 4 : Gred Jawatan Responden

\begin{tabular}{|l|l|l|}
\hline Gred Jawatan & Bilangan Responden & Responden \% \\
\hline DH 29/32/34 & 2 & $4.7 \%$ \\
\hline DH 41 & 38 & $88.4 \%$ \\
\hline DH 44 & 3 & $7.0 \%$ \\
\hline DH 48 & 0 & 0 \\
\hline Total & 43 & 100 \\
\hline
\end{tabular}

Tabel 5

Jadual 5 : Tempoh Berkhidmat

\begin{tabular}{|c|l|l|}
\hline Tempoh Berkhidmat & Bilangan Sampel & Sampel \% \\
\hline Kurang 3 tahun & 11 & $25.6 \%$ \\
\hline 3 hingga 6 tahun & 4 & $9.3 \%$ \\
\hline 6 hingga 12 tahun & 27 & $62.8 \%$ \\
\hline Lebih 12 tahun & 1 & $2.3 \%$ \\
\hline Total & 43 & 100 \\
\hline
\end{tabular}

Tabel 6

Jadual 6: Min Keseluruhan bagi tahap pengetahuan PPPT terhadap program SIP

\begin{tabular}{|l|l|l|}
\hline Tahap Pengetahuan & Min & Tahap \\
\hline Kesedaran terhadap kewujudan program SIP . & 3.63 & Tinggi \\
\hline Kefahaman tentang kepentingan program SIP. & 3.49 & Sederhana \\
\hline $\begin{array}{l}\text { Kefahaman tentang kaedah permohonan program } \\
\text { SIP. }\end{array}$ & 2.95 & Sederhana \\
\hline $\begin{array}{l}\text { Kefahaman tentang syarat-syarat kelayakan } \\
\text { memohon program SIP. }\end{array}$ & 2.98 & Sederhana \\
\hline $\begin{array}{l}\text { Kefahaman mengenai kriteria pemilihan tempat } \\
\text { latihan program SIP. }\end{array}$ & 2.81 & Sederhana \\
\hline Kefahaman tentang tatacara program SIP. & 2.70 & Sederhana \\
\hline Kefahaman tentang tempoh program SIP & 3.00 & Sederhana \\
\hline Kesedaran mengenai tuntutan program SIP dan & 2.91 & Sederhana \\
\hline
\end{tabular}




\begin{tabular}{|c|c|c|}
\hline Tahap Pengetahuan & Min & Tahap \\
\hline $\begin{array}{l}\text { elaun perjalanan boleh dibuat selepas menjalani } \\
\text { program SIP. }\end{array}$ & & \\
\hline $\begin{array}{l}\text { Kefahaman mengenai kadar tuntutan berkursus dan } \\
\text { elaun perjalanan. }\end{array}$ & 2.58 & Sederhana \\
\hline $\begin{array}{l}\text { Kefahaman tentang tanggungjawab yang perlu } \\
\text { dilaksanakan selepas tamat program SIP. }\end{array}$ & 2.79 & Sederhana \\
\hline Total Min & 2.98 & Sederhana \\
\hline
\end{tabular}

Tabel 7

Jadual 7 : Dapatan Ujian Oneway ANOVA

\begin{tabular}{|c|c|c|c|c|c|c|}
\hline & & Sum of Squares & df & Mean Square & $\mathrm{F}$ & Sig. \\
\hline b1 & $\begin{array}{l}\text { Between Groups } \\
\text { Within Groups } \\
\text { Total }\end{array}$ & $\begin{array}{l}.038 \\
12.009 \\
12.047\end{array}$ & $\begin{array}{l}2 \\
40 \\
42\end{array}$ & $\begin{array}{l}.019 \\
.300\end{array}$ & .063 & .939 \\
\hline b2 & $\begin{array}{l}\text { Between Groups } \\
\text { Within Groups } \\
\text { Total }\end{array}$ & $\begin{array}{l}.104 \\
16.640 \\
16.744\end{array}$ & $\begin{array}{l}2 \\
40 \\
42\end{array}$ & $\begin{array}{l}.052 \\
.416\end{array}$ & .125 & .883 \\
\hline b3 & $\begin{array}{l}\text { Between Groups } \\
\text { Within Groups } \\
\text { Total }\end{array}$ & $\begin{array}{l}.644 \\
25.263 \\
25.907\end{array}$ & $\begin{array}{l}2 \\
40 \\
42\end{array}$ & $\begin{array}{l}.322 \\
.632\end{array}$ & .510 & .605 \\
\hline b4 & $\begin{array}{l}\text { Between Groups } \\
\text { Within Groups } \\
\text { Total }\end{array}$ & $\begin{array}{l}.582 \\
30.395 \\
30.977\end{array}$ & $\begin{array}{l}2 \\
40 \\
42\end{array}$ & $\begin{array}{l}.291 \\
.760\end{array}$ & .383 & .684 \\
\hline b5 & $\begin{array}{l}\text { Between Groups } \\
\text { Within Groups } \\
\text { Total }\end{array}$ & $\begin{array}{l}1.977 \\
24.535 \\
26.512\end{array}$ & $\begin{array}{l}2 \\
40 \\
42\end{array}$ & $\begin{array}{l}.988 \\
.613\end{array}$ & 1.611 & .212 \\
\hline b6 & $\begin{array}{l}\text { Between Groups } \\
\text { Within Groups } \\
\text { Total }\end{array}$ & $\begin{array}{l}1.728 \\
27.342 \\
29.070\end{array}$ & $\begin{array}{l}2 \\
40 \\
42\end{array}$ & $\begin{array}{l}.864 \\
.684\end{array}$ & 1.264 & .294 \\
\hline b7 & $\begin{array}{l}\text { Between Groups } \\
\text { Within Groups } \\
\text { Total }\end{array}$ & $\begin{array}{l}2.070 \\
23.930 \\
26.000\end{array}$ & $\begin{array}{l}2 \\
40 \\
42\end{array}$ & $\begin{array}{l}1.035 \\
.598\end{array}$ & 1.730 & .190 \\
\hline b8 & $\begin{array}{l}\text { Between Groups } \\
\text { Within Groups } \\
\text { Total }\end{array}$ & $\begin{array}{l}1.409 \\
26.219 \\
27.628\end{array}$ & $\begin{array}{l}2 \\
40 \\
42\end{array}$ & $\begin{array}{l}.704 \\
.655\end{array}$ & 1.074 & .351 \\
\hline b9 & $\begin{array}{l}\text { Between Groups } \\
\text { Within Groups } \\
\text { Total }\end{array}$ & $\begin{array}{l}2.465 \\
34.000 \\
36.465\end{array}$ & $\begin{array}{l}2 \\
40 \\
42\end{array}$ & $\begin{array}{l}1.233 \\
.850\end{array}$ & 1.450 & .247 \\
\hline b10 & $\begin{array}{l}\text { Between Groups } \\
\text { Within Groups } \\
\text { Total }\end{array}$ & $\begin{array}{l}1.248 \\
27.868 \\
29.116\end{array}$ & $\begin{array}{l}2 \\
40 \\
42\end{array}$ & $\begin{array}{l}.624 \\
.697\end{array}$ & .896 & .416 \\
\hline
\end{tabular}


Tabel 8

Jadual 8: Faktor-faktor tidak mengikuti Program SIP

\begin{tabular}{|c|c|c|c|c|}
\hline Bil & Faktor-faktor & $\begin{array}{l}\text { Setuju } \\
(\%)\end{array}$ & $\begin{array}{l}\text { Tidak } \\
\text { setuju } \\
(\%)\end{array}$ & $\begin{array}{l}\text { Tidak berkenaan } \\
\text { (Telah mengikuti } \\
\text { program SIP) } \\
(\%)\end{array}$ \\
\hline 1 & Bebanan tugas di jabatan yang banyak. & 72.1 & 16.3 & 11.6 \\
\hline 2 & Urusan keluarga. & 48.9 & 39.6 & 11.6 \\
\hline 3 & Senarai tempat latihan yang terhad. & 48.8 & 40.2 & 11.6 \\
\hline 4 & Tiada galakan dari pihak pengurusan. & 41.8 & 46.5 & 11.6 \\
\hline 5 & Kerumitan prosedur. & 41.9 & 46.5 & 11.6 \\
\hline 6 & $\begin{array}{l}\text { Sesi pengambilan program SIP tidak } \\
\text { sesuai. }\end{array}$ & 34.9 & 53.5 & 11.6 \\
\hline 7 & Tiada kerjasama dari pihak industri. & 25.6 & 62.8 & 11.6 \\
\hline 8 & $\begin{array}{l}\text { Tidak mahu tugas tambahan selepas } \\
\text { tamat menjalani program SIP seperti } \\
\text { membuat laporan dan sumbangan. }\end{array}$ & 23.3 & 65.1 & 11.6 \\
\hline Bil & Faktor-faktor & $\begin{array}{l}\text { Setuju } \\
(\%)\end{array}$ & $\begin{array}{l}\text { Tidak } \\
\text { setuju } \\
(\%)\end{array}$ & $\begin{array}{l}\text { Tidak berkenaan } \\
\text { (Telah mengikuti } \\
\text { program SIP) } \\
(\%)\end{array}$ \\
\hline 9 & Bukan bidang hospitaliti. & 23.3 & 65.1 & 11.6 \\
\hline 10 & $\begin{array}{l}\text { Program SIP tidak mendatangkan } \\
\text { faedah kepada P\&P. }\end{array}$ & 9.3 & 79.1 & 11.6 \\
\hline
\end{tabular}

